is nephrotoxic when included in analgesic mixtures or given to patients with pre-existing analgesic nephropathy. Nevertheless, they give reassuring evidence that aspirin used as sole treatment for rheumatoid arthritis over many years in standard therapeutic dosage carries little or no risk of renal damage.

${ }^{1}$ Molland EA. Experimental renal papillary necrosis. Kidney Int 1978;13: 5-14.

${ }^{2}$ Nanra RS, Stuart-Taylor J, De Leon AH, White KH. Analgesic nephropathy; etiology, clinical syndrome, and clinicopathologic correlations in Australia. Kidney Int 1978;13:79-92.

${ }^{3}$ New Zealand Rheumatism Association Study. Aspirin and the kidney. Br Med F 1974 ;i :593-6.

4 Macklon AF, Craft AW, Thompson M, Kerr DNS. Aspirin and analgesic nephropathy. Br Med f 1974 ; i :597-600.

${ }^{5}$ Chantler C, Garnett ES, Parsons V, Veall N. Glomerular filtration rate measurement in man by the single injection method using ${ }^{51} \mathrm{Cr}$-EDTA. Clin Sci $1969 ; 37: 169-80$.

(Accepted 12 November 1981)

Royal Victoria Infirmary, Newcastle upon Tyne NE1 4LP

$S M$ AKYOL, MD, research fellow in rheumatology

M THOMPSON, MD, FRCP, consultant rheumatologist

D N S KERR, MSC, FRCP, professor of medicine

\section{Ovulation side and occurrence of mittelschmerz in spontaneous and induced ovarian cycles}

Real-time pelvic ultrasonography was used to investigate the frequency with which ovulation alternated between the two ovaries in 48 women studied over four or more consecutive menstrual cycles. In addition the occurrence and site of mittelschmerz was related to the side of follicular rupture.

\section{Subjects, methods, and results}

We recruited into the study 15 healthy women (group 1) aged 23 to 35 years with regular menstrual cycles ( 25 to 33 days). In addition, 17 infertile patients undergoing treatment with clomiphene citrate $(50$ to $200 \mathrm{mg} /$ day) for days 1 to 5 of the menstrual cycle (group 2) and 24 patients receiving treatment with human menopausal gonadotrophin and human chorionic gonadotrophin (group 3) gave informed consent for ultrasonic scanning at least twice in the immediate periovulatory period for a minimum of four consecutive menstrual cycles. The women were scanned daily until there was good evidence that follicular rupture had occurred. ${ }^{1}$ Eight subjects (four in group 2, four in group 3) who conceived during treatment were excluded from the analysis; 48 patients completed the study.

A real-time mechanical sector scanner (ATL model $851 \mathrm{~B}$ ) was used and the women examined with the full-bladder technique, as described by Donald. ${ }^{2}$ Transverse and longitudinal scans were performed on both ovaries and the mean diameter of each follicle calculated. ${ }^{13}$ Each woman was asked to record the presence and site of mittelschmerz. Additional evidence of ovulation was obtained for all subjects from basal body temperature records and plasma progesterone concentration $(>15 \mathrm{nmol} / 1 ;>4.7 \mathrm{ng} / \mathrm{ml})$ on day 21 of the menstrual cycle (or day seven after an injection of human chorionic gonadotrophin).

The table shows the number of women from each group with consecutive

Sequence of ovulation in 48 women over four consecutive ovarian cycles and occurrence of mittelschmerz in relation to side of follicular rupture

\begin{tabular}{|c|c|c|c|}
\hline & \multicolumn{3}{|c|}{ Ovarian cycle } \\
\hline & Spontaneous & $\begin{array}{c}\text { Clomiphene } \\
\text { induced }\end{array}$ & $\begin{array}{c}\text { Human } \\
\text { menopausal/ } \\
\text { human } \\
\text { chorionic } \\
\text { gonadotrophin } \\
\text { induced }\end{array}$ \\
\hline \multirow{3}{*}{$\begin{array}{l}\text { No of women } \\
\text { No (\%) with ovulation from } \\
\text { alternate ovaries } \\
\text { No of cycles } \\
\text { No }(\%) \text { with mittelschmerz } \\
\text { Site of pain relative to follicular } \\
\text { rupture: } \\
\text { Same No }(\%) \\
\text { Central No }(\%) \\
\text { Opposite No }(\%)\end{array}$} & 15 & 13 & 20 \\
\hline & $\begin{array}{l}12(80) \\
62(23) \\
14(23)\end{array}$ & $\begin{array}{r}8(62) \\
56 \\
8(14)\end{array}$ & $\begin{array}{l}6(30) \\
87 \\
29(33)\end{array}$ \\
\hline & $\begin{aligned} & 11(79) \\
& 2(14) \\
& 1(7)\end{aligned}$ & $\begin{array}{l}6(75) \\
1(12 \cdot 5) \\
1(12 \cdot 5)\end{array}$ & $\begin{aligned} & 27(93) \\
& 2(7) \\
& 0\end{aligned}$ \\
\hline
\end{tabular}

ovulation from alternate ovaries over at least four consecutive menstrual cycles, together with the frequency of mittelschmerz and its relation to the side of follicular rupture. Bilateral ovulation occurred in two patients from group $2(15 \%)$ and four patients from group $3(20 \%)$.

\section{Comment}

It is generally assumed that ovulation occurs an equal number of times from the left and right ovaries, and it was on the basis of this assumption that Jeffcoate ${ }^{4}$ suggested that efforts should not be made to conserve a compromised ovary on the side of an ectopic pregnancy. It was argued that the removal of the ovary together with the tube and developing embryo would almost certainly double the number of subsequent ovulations from the remaining ovary, thus increasing the chances of a subsequent conception. It was also reasoned that the chances of a further ectopic pregnancy would be reduced, since an ovum from the ovary on the affected side could theoretically migrate across the peritoneum to the remaining tube.

If ovulation occurs at random from either ovary there is only a $12.5 \%$ chance of the process alternating between both gonads over four consecutive cycles. Our serial use of pelvic ultrasonography, however, provided good evidence that ovulation occurs from alternate ovaries in $80 \%$ of healthy subjects with regular menstrual cycles. Furthermore, the occurrence of more random ovulation from either ovary in $38 \%$ of patients after clomiphene citrate and in $70 \%$ of patients given human gonadotrophins may have therapeutic implications if there is a difference in the function of both tubes. It is difficult, however, to assess this facet of reproductive function in an individual patient.

Mittelschmerz is thought to occur in about half of all women at some time during their reproductive life. The pain has been described as acute and peristaltic; it often occurs on the same side and may not change when the other ovary produces the active follicle. The cause is unknown but may be due to tubal, uterine, or caecal spasm, or increased tension in the ovary or Graafian follicle. Another possible explanation concerns irritation of the peritoneum arising from the discharge of blood and fluid from the ruptured follicle. Supportive evidence was presented by Hann et al, ${ }^{4}$ who, using ultrasound, detected fluid in the pouch of Douglas within two days of follicular rupture in four of six patients who had mittelschmerz. Later, however, O'Herlihy et $a l^{5}$ reported that 26 of 34 women with mittelschmerz experienced the symptom on the same day as the peak of plasma luteinising hormone and in 33 the pain preceded follicular rupture as determined by ultrasonography.

In our study mittelschmerz occurred on the same side as follicular rupture in $86 \%$ of all subjects who experienced the symptom and would, therefore, appear to be a good index for the immediate prediction and detection of ovulation. Central mittelschmerz may be explained on the basis of the mobility of the ovary. Mittelschmerz occurring on the opposite side to follicular rupture is more difficult to explain but might be due to smaller follicles responding to an increase in circulating luteinising hormone. Mittelschmerz occurring only when ovulation takes place from a particular ovary may be explained on the basis of unilateral periovarian adhesions restricting the response of the follicles or ovary to luteinising hormone.

${ }^{1}$ Queenan JT, O'Brien GD, Simpson J, Bains L, Collins WP, Campbell S. Ultrasound scanning of ovaries to detect ovulation. Fertil Steril 1980; 34:99-105.

2 Donald I. Use of ultrasound in the diagnosis of abdominal swellings. $\mathrm{Br}$ Med $\mathcal{F}$ 1963;ii:1154-5.

${ }^{3}$ Kerin JF, Edmonds DK, Warnes GM, et al. Morphological and functional relations of Graafian follicle growth to ovulation in women using ultrasonic, laparoscopic and biochemical measurement. $\mathrm{Br} \mathcal{F}$ Obstet Gynaecol $1981 ; 88: 81-90$.

${ }^{4}$ Hann LE, Hall DA, Black EB, Ferrucci JT. Mittelschmerz: sonographic demonstration. $\mathcal{F} A M A 1979 ; 241: 2731-2$

5 O'Herlihy C, Robinson HP, Ch de Crespigny LJ. Mittelschmerz is a preovulatory symptom. Br Med f 1980;280:986.

(Accepted 11 November 1981)

Department of Obstetrics and Gynaecology, King's College Hospital Medical School, London SE5 8RX

A O MARINHO, MB, FMCOG, (present address: Department of Obstetrics and Gynaecology, University College Hospital, Ibadan, Nigeria)

H N SALLAM, MB, DGo, clinical research fellow

L GOESSENS, $M D$, clinical assistant

W P COL.LINS, PHD, DSC, professor in reproductive biochemistry

S CAMPBELL, MB, FRCOG, head of department 